\title{
ОСОБЕННОСТИ ТЕЧЕНИЯ ГИПОКСИЧЕСКИ-ИШЕМИЧЕСКОЙ ЭНЦЕФАЛОПАТИИ У НОВОРОЖДЕННЫХ ДЕТЕЙ РАЗЛИЧНОГО ГЕСТАЦИОННОГО ВОЗРАСТА
}

\author{
1А.А.Мамедова, 2Р.К.Ширалиева \\ ${ }^{1}$ НИИ Педиатрии им.К.Я.Фараджевой, Баку; \\ ${ }_{2}^{2}$ Азербайдэсанский Государственный Институт Усовершенствования Врачей им. А.Алиева, Баку
}

Проблема изучения перинатальной патологии нервной системы у ново-рожденных детей различного гестационного возраста остается актуальной, что обусловлено прогрессирующим ростом частоты церебральных наруше-ний у новорожденных - 80\% (Барашнев Ю. И., 2005; Баранов А. А., 2008). Перинатальные факторы, вызывающие развитие гипоксически-ишемической энцефалопатии приводят в дальнейшем к неврологическим и соматическим расстройствам, инвалидизации, социальной дизадаптации, что придает дан-ной проблеме медико-социальную значимость. Формирование церебрального паралича у 50\% детей различного гестационного возраста имеет пренатальную этиологию и в $36 \%$ - перинатальное или неонатальное происхождение (Пальчик А.Б., 2006; Яцык Г.В. и др., 2007). Формирование патоморфологических изменений головного мозга, толерантность к гипоксии, особенности адаптации, возможность прогнозирования у новорожденных детей различного гестационного возраста неясны (Шабалов Н.П., 2004; Ballanyi К., 2004; Murata Y. et al, 2005). В связи с чем нами обследованы 54 новорожденных детей различного гестационного возраста. По степени тяжести перинатальной ги-поксии все дети были разделены на 3 группы: I-я группа - 32(59,3\%) детей, перенесших перинатальную гипоксию легкой степени тяжести. Эти дети ро-дились в 32-36 нед. гестации, с весом 1310-2390г, с оценкой по шкале Апгар 6-7 баллов; II-ю группу составили $12(22,2 \%)$ новорожденных, родив-шихся в срок 34-36 нед. с весом 2450-2870г, оценкой по шкале Апгар 4-5 баллав и перенесших тяжелую интранатальную асфиксию. Контрольная III группа - 10(18,5\%) доношенных ребенка весом 2600-2950г, родились с оценкой по шкале Апгар 7-8 баллов. У 17(38,6\%) новорожденных из I-й и II-й клинических групп был отмечен синдром фетофетальной трансфузии, у
11(25\%) асимметричная форма задержки развития плода, у 9(20,5\%) - диссоциированное развитие плодов. Допплерографические исследования выявили в 1-е сутки жизни почасовое колебание IR кровотока в бассейнах передней, средней и базиллярной артерий во всех трех клинических группах. У детей из I-й группы IR повышался на 1-е сутки и о снижался к 4-5-м суткам. У этих детей к 4-м суткам формировались субэпендимальные гематомы, а в конце неонатального периода определялась персистирующая вентрикулодилатация. У детей отмечена асимметрия нейросонографических и допплерометрических показателей. У 2$\mathrm{x}$ новорожденных наблюдался стойкий длительный отек мозга, вазоспазм, сопровождающийся повышением IR до 0,77-0,81, который сочетался с синдромом угнетения, а затем усугублялся судорожным синдромом. У ребенка из I-ой группы отмечался синдром повышенной нервно-рефлекторной возбудимости при IR 0,76-0,77. После формирования субэпендимальной кисты, IR снижался до 0,52-0,63 и в дальнейшем сопровождался легкой вентрикулодилатацией. В течение первого года жизни у 3-х детей со среднетяжелой церебральной ишемией преобладал синдром повышенной нервно-рефлекторной возбудимости, пик которого приходился на 2-3-й месяц жизни, синдром двигательных нарушений и судорожный синдром. При этом у 5-ти детей с перивентрикулярным кровоизлиянием I-й степени протекало бессимптомно. Транзиторная вентрикулодилатация исчезала на 7-8 месяце жизни, субэпендимальная псевдокиста подвергалась полному лизису к концу первого года жизни. У детей из II-й группы судорожный синдром переходил в коматозное состояние на фоне IR 0,78-0,84, а после купирования судорог постепенно формировалась задержка психомоторного развития, со-провождавшаяся прогрессирующей вентрикулодилатацией. 